\title{
Genç İşsizliğin Yetişkin İşsizlik ile Karşılaştırmalı Analizi: Türkiye için Kalman Filtresi Yöntemi ile Dinamik Bir Uygulama
}

\section{Comparative Analysis of Young Unemployment Versus Adult Unemployment: A Dynamic Analysis with Kalman Filter Method}

\author{
Pınar Karahan-Dursun ${ }^{1}$ - Nilgün Çağlarırmak Uslu²
}

Başvuru Tarihi: 03.09.2018

Kabul Tarihi: 13.09.2019

\section{Öz}

Genç işsizliğin ekonomik konjonktür hareketlerinden ve son yaşanan küresel finans krizinden yetişkin işsizliğe göre daha fazla etkilendiği, uluslararası yazında tartışılmaktadır. Bu çalışmada, global makroekonomik sorunların başında gösterilen genç işsizliğin boyutları yetişkin işsizlik ile karşılaştırılmalı olarak incelenmiş olup, küresel finans krizinin genç işsizlik üzerindeki göreli etkisi dinamik olarak analiz edilmiştir. Ampirik analizde, konjonktürü temsilen ekonomik büyüme oranlarının genç ve yetişkin işsizlik oranları üzerindeki etkileri 2006:Q1-2017:Q4 dönemi için ARDL modeli ve Kalman Filtresi yöntemi kullanılarak Türkiye için incelenmiştir. Elde edilen sonuçlar, büyümenin genç işsizlik üzerinde daha yüksek negatif etkisinin olduğunu ve genç işsizliğin, küresel finans krizi dönemine denk gelen ekonomik daralma dönemlerinden daha fazla etkilendiŭini göstermiştir.

Anahtar Kelimeler: Genç Işsizlik, Yetişkin İşsizlik, Ekonomik Büyüme, ARDL Modeli, Kalman Filtresi

\begin{abstract}
It argues that youth unemployment has been more affected to business cycle and recent global financial crisis than adult unemployment. In this study, the extents of youth unemployment, which is the one of the macroeconomic problems, has been examined with adult unemployment comparatively and investigated the relative effect of global finance crisis on youth unemployment dynamically. We employ ARDL model and Kalman Filter method covering the period of 2006:Q12017:Q4 for Turkey in order to investigate effects of economic growth rates, representing as business cycle, on youth and adult unemployment rates in empirical analysis. The results indicate that growth has a higher negative effect on youth unemployment and youth unemployment has been more affected than the period of economic recession corresponding to global financial crisis period.
\end{abstract}

Keywords: Youth Unemployment, Adult Unemployment, Economic Growth, ARDL Model, Kalman Filter Method

\footnotetext{
${ }^{1}$ Anadolu Üniversitesi, pkarahan@aandolu.edu.tr, ORCID: 0000-0002-8289-6570

${ }^{2}$ Anadolu Üniversitesi İktisat Fakültesi, ncaglarirmak@anadolu.edu.tr, ORCID: 0000-0001-6254-5784
} 


\section{Giriş}

15-24 yaş arasındaki nüfusu temsil eden gençler toplumun önemli bir kaynağını oluşturmaktadır. Dünya'da toplam nüfusunun \%18'inden ve toplam işgücünün \% 15 'inden fazlasını oluşturan gençlerin karşılaştıkları işgücü piyasası sorunlarını ele almak, dünya çapında sürdürülebilir büyüme ve adil bir sosyo-ekonomik çevrenin gerçekleştirilmesi açısından önem taşımaktadır (ILO, 2016, s. 1). Eğitimlerini tamamladıktan sonra erken çalışma yıllarında işsiz kalanların demoralize olması ve gençlerin beşeri sermayeleri ve işin gerektirdikleri konusunda kendilerini yetersiz görmeleri sosyal dişlanmaya sebep olmaktadır. Genç işsizliğin, gençlerin demoralize olması ve sosyal dışlanma sorunlarına neden olmasının yanında, atıl işgücü potansiyelini göstermesi bakımından ekonomik büyüme üzerinde negatif bir etkiye yol açarak ekonominin tümü için bir sorun oluşturmaktadır (Gomez-Salvador ve Leiner-Killinger, 2008, s. 8).

Gençlerin ekonomik konjonktür hareketlerine yetişkinlerden daha duyarlı olduğu ve ekonomik kriz dönemlerinde genç işsizliğin yetişkin işsizlikten daha fazla arttığını ortaya koyan uluslararası yazında yapılmış çalışmalar mevcuttur (Jimeno ve Rodriguez-Palenzuela, 2002; Bell ve Blanchflower, 2010; O’Higgins, 2010; OECD, 2008; Scarpetta vd., 2010; Hutengs ve Stadtmann, 2014). Gençler, genellikle ekonomik kriz zamanlarında işlerini ilk kaybeden ve ekonomi toparlandığında en son istihdam edilenlerdir. 2009 yılında, Dünya'da 211 milyon işsizin \%40’ını (yaklaşık 81 milyon) 15-24 yaş grubu oluşturmuş ve genç işsizliğin sayısı 6.7 milyon artmıştır (O’Higgins, 2010, s. v-1).

Genç işsizlikte görülen yüksek konjonktürel oynaklığın çeşitli nedenleri vardır: i) genç çalışanlar genellikle düşük iş güvencesine sahiptir, ii) gençlerin yetişkinlere göre tecrübelerinin daha düşük (ya da tecrübesiz) olması ve şirketlerin gençlere verdiği iş eğitimlerini en az düzeyde tutmaları nedeniyle gençlerin işten çıkarılmasının işveren açısında kaybı daha düşüktür, iii) kıdem tazminatları, çalışanın hizmet süresi ile birlikte arttı̆̆ı ve hizmet süresi yaş ile birlikte arttığı için gençleri işten çıkarmak işveren için daha az maliyetlidir, iv) gençlerin yetişkinlere göre gönüllü olarak iş değiştirmelerinin daha muhtemel olması, genç çalışanların öncelikli olarak işten çıkartılmalarına neden olmaktadır (Görlich vd., 2013, s. 3-4; O’Higgins, 2001, s. 4041; Pagés ve Montenegro, 2007, s. 110). İşten çıkarmalar olmasa bile; işe alımların durduğu durumlarda, eğitimlerini tamamlayıp işgücü piyasasına girmeye çalışan gençler olacağı için genç işsizlik artmaya devam edecektir (Martin, 2009, s. 5).

Bu çalışmada, Türkiye'de 2006:Q1-2017:Q4 dönemi için genç işsizliğin ekonomik konjonktür duyarlılığının yetişkin işsizlikten farklı olup olmadığı araştırılmıştır. Bu amaçla, ekonomik büyümenin genç işsizliği yetişkin işsizlikten farklı yönde ve ölçüde etkileyip etkilemediği zamana göre değişen parametre yöntemi (TVP) ile test edilmiştir. Ampirik analizde, Türkiye'de ekonomik büyümenin genç işsizlik ve yetişkin işsizlik üzerindeki uzun ve kısa dönem etkileri ARDL modeli kullanılarak; ekonomik büyümenin genç işsizlik ve yetişkin işsizlik üzerindeki dinamik etkileri Kalman filtresi yöntemi kullanılarak incelenmiştir. Çalışma, araştırma konusu ve uygulanan ekonometrik teknik açısından, Türkiye'de genç işsizliğe ilişkin yapılmış çalışmalardan ayrılmaktadır. 
Çalışmanın ikinci bölümünde genç işsizliğin boyutları yetişkin işsizlik ile birlikte karşılaştırmalı olarak incelenmiş olup, genç işsizlik sorunu cinsiyet bazında ele alınmıştır. Üçüncü bölümde, genç işsizlik ile ilgili yapılmış bazı ampirik çalışma özetlerine yer verilmiştir. Dördüncü bölümde, kullanılan veri seti ve yöntem açıklanmış, ampirik analiz bulguları paylaşılmıştır.

\section{Genç İşsizliğin Boyutları}

Gençlerin işsiz kalma olasılığı yetişkinlere göre üç katıdır. 2016 yılı itibariyle, Dünya genelinde genç işsizlik oranı \%13 olmakla birlikte yetişkin (25+) işsizlik oranı \%4.4 olarak gerçekleşmiştir. Global olarak, genç/yetişkin işsizlik oranında son yıllarda çok az değişim meydana gelmiştir 3 . Bu durum, emek piyasasında özellikle gençlerin dezavantajlı olduğunu açıklamaktadır (ILO, 2017, s. 1). Genç işsizlik oranlarının yetişkin işsizlik oranlarından oldukça yüksek olmasının temel sebebi, gençlerin beşeri sermaye ve verimlilik düzeylerinin yetişkinlere göre daha düşük düzeyde ve/veya farklı nitelikte olmasıdır (Choudhry vd., 2012, s. 78-79).

Tablo 1, 2008-2017 yılları arasında global ve bölgesel düzeyde gerçekleşen genç/yetişkin işsizlik oranlarını göstermektedir. Tablo 1 incelendiğinde, Güney Doğu Asya ve Pasifik bölgesinde 2011 yılından itibaren genç işsizlik oranlarının yetişkin işsizlik oranlarının beş katından daha fazla olduğu görülmektedir. Bu bölgeyi Arap ülkeleri ve Güney Asya bölgeleri izlemektedir. 2017 yılı itibariyle, Tablo 1'de yer alan on iki bölgenin yarısından fazlasında, genç işsizlik oranları yetişkin işsizlik oranlarının en az üç katı düzeyinde gerçeklemiştir.

Tablo 1. Global ve Bölgesel Genç/Yetişkin İşsizlik Oranları (2008-2017)

\begin{tabular}{|l|l|l|l|l|l|l|l|l|l|l|}
\hline & $\mathbf{2 0 0 8}$ & $\mathbf{2 0 0 9}$ & $\mathbf{2 0 1 0}$ & $\mathbf{2 0 1 1}$ & $\mathbf{2 0 1 2}$ & $\mathbf{2 0 1 3}$ & $\mathbf{2 0 1 4}$ & $\mathbf{2 0 1 5}$ & $\mathbf{2 0 1 6}$ & $\mathbf{2 0 1 7}$ \\
\hline Dünya & 3 & 2.8 & 2.8 & 2.9 & 2.9 & 2.9 & 2.9 & 3 & 3 & 3 \\
\hline Kuzey Afrika & 3.5 & 3.6 & 3.4 & 3.2 & 3.6 & 3.5 & 3.3 & 3.3 & 3.3 & 3.5 \\
\hline Sahra Altı Afrika & 2 & 2 & 2 & 1.9 & 1.9 & 1.9 & 1.9 & 1.9 & 1.9 & 2 \\
\hline $\begin{array}{l}\text { Latin Amerika ve } \\
\text { Karayipler }\end{array}$ & 2.9 & 2.8 & 2.9 & 2.9 & 2.9 & 3 & 3.1 & 3.1 & 3.1 & 3 \\
\hline Kuzey Amerika & 2.7 & 2.2 & 2.2 & 2.3 & 2.4 & 2.5 & 2.6 & 2.7 & 2.5 & 2,5 \\
\hline Arap Ülkeleri & 4.4 & 4.3 & 4.3 & 4.3 & 4.3 & 4.3 & 4.3 & 4.5 & 4.6 & 4,2 \\
\hline Doğu Asya & 3.1 & 3 & 2.9 & 3 & 3 & 2.9 & 2.9 & 2.9 & 2.8 & 2,7 \\
\hline $\begin{array}{l}\text { Güney Doğu Asya ve } \\
\text { Pasifik }\end{array}$ & 4.6 & 4.5 & 4.7 & 5 & 5.3 & 5.8 & 5.4 & 5.6 & 5.4 & 6,3 \\
\hline Güney Asya & 3.6 & 3.4 & 4 & 4.1 & 4.1 & 4.2 & 4.2 & 4.1 & 3.9 & 4 \\
\hline $\begin{array}{l}\text { Kuzey, Güney ve Batı } \\
\text { Avrupa }\end{array}$ & 2.6 & 2.5 & 2.5 & 2.5 & 2.4 & 2.4 & 2.3 & 2.4 & 2.4 & 2,4 \\
\hline Doğu Avrupa & 2.8 & 2.7 & 2.7 & 2.9 & 3.1 & 3 & 3.1 & 3.2 & 3.3 & 3,4 \\
\hline Merkez ve Batı Asya & 2.3 & 2.2 & 2.3 & 2.3 & 2.3 & 2.3 & 2.2 & 2.2 & 2.3 & 2,3 \\
\hline
\end{tabular}

Kaynak: ILO, Global Employment Trends for Youth, 2017, s. 103; ILOSTAT.

Şekil 1, 2017 yılı itibariyle OECD ülkelerinde gerçekleşen genç işsizlik ve yetişkin işsizlik oranlarını göstermektedir. 36 ülkeyi kapsayan OECD ülkelerinin yaklaşık \%80,5’inde (29 ülke), genç işsizlik oranları yetişkin işsizlik oranlarından üç kat daha fazladır. En yüksek genç işsizlik $(\% 43,6)$ ve yetişkin işsizlik oranına $(\% 20,2)$ Yunanistan, en düşük genç işsizlik oranına Japonya $(\% 4,7)$ ve en düşük yetişkin işsizlik oranına İzlanda (\%1,7) sahiptir. 2017 yılı itibariyle OECD

\footnotetext{
3 Genç/yetişkin işsizlik oranının 1'den büyük olması, genç işsizlik oranının yetişkin işsizlik oranından fazla olduğunu; oranın 1'den küçük olması, yetişkin işsizlik oranının genç işsizlik oranından fazla olduğu anlamına gelmektedir.
} 
ülkeleri arasında Türkiye, genç işsizlik oranında \%20,6 ile en yüksek altıncı, yetişkin işsizlik oranında \%9.2 ile Yunanistan, İspanya ve İtalya'dan sonra en yüksek dördüncü ülke olarak yer almaktadır.

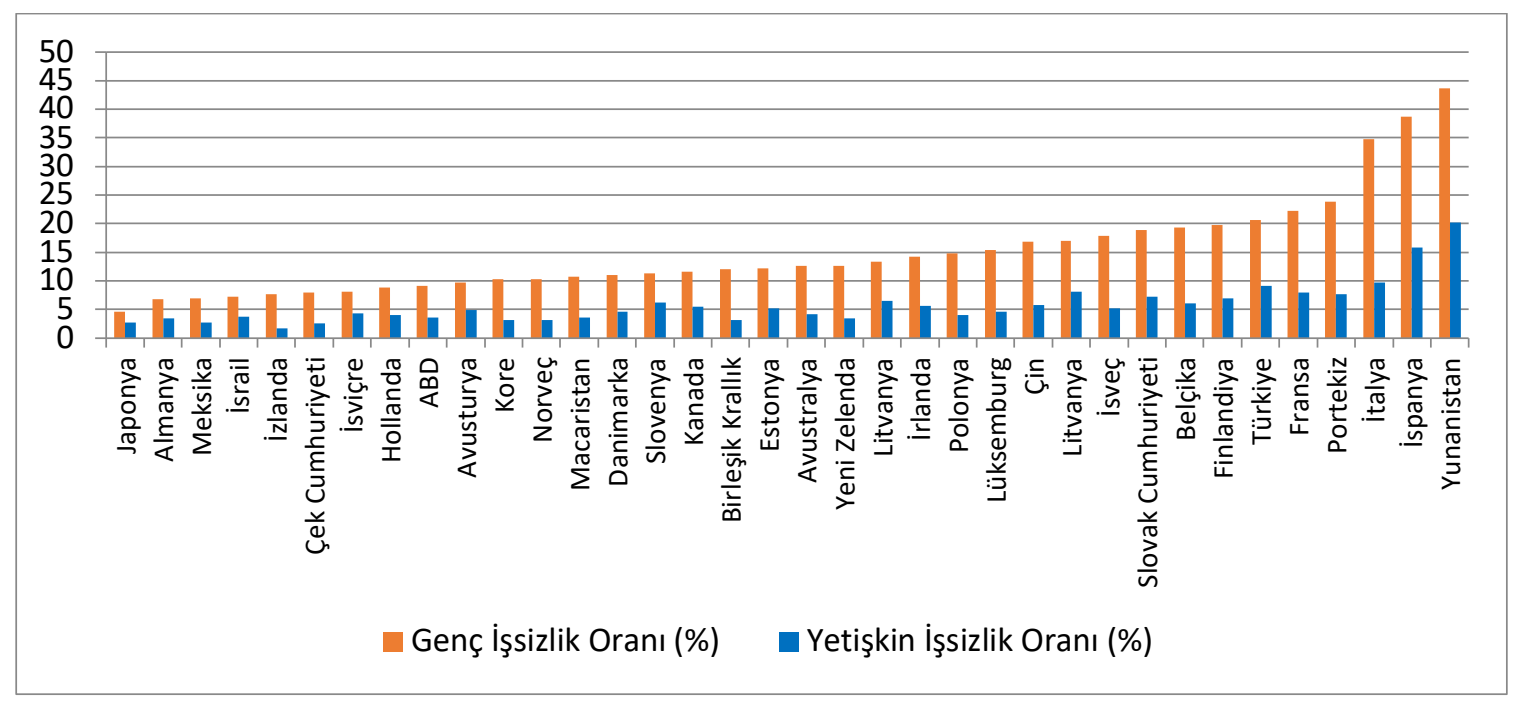

Kaynak: OECD ve ILOSTAT verileri kullanılarak oluşturulmuştur.

\section{Şekil 1. OECD Ülkelerinde Genç İssizlik ve Yetişkin İ̧ssizlik Oranları (2017, \%)}

Birçok Avrupa ülkesinde yüksek genç işsizlik oranları, çoğunlukla 2007-2010 yılları arasında yaşanan global finansal ve ekonomik krizlere dayanmaktadır (Dietrich, 2012, s. 3). Global ekonomik kriz, genç işsizliği önemli ölçüde arttırmıştır. 2008 yılında, OECD bölgesinde genç/yetişkin işsizlik oranı 2.8 düzeyinde gerçekleşmiş olup, genç işsizlik 2009 yılı sonuna kadar iki yll içinde \%6 artarak yaklaşık \%19 seviyesine yükselmiştir (Scarpetta vd., 2010, s. 4-11). Gençlerin ekonomik daralma dönemlerinde yetişkinlerden daha fazla etkilenmelerindeki problem, sadece genç işsizlik oranlarının yetişkin işsizlik oranlarından daha fazla artması değildir. Burada temel nokta, krizden etkilenen gençlerin krizin etkilerine karşı yetişkinlerden daha savunmasız olmaları ve bu etkilerin gençler üzerinde daha uzun süreli olmasıdır (O’Higgins, 2010, s. v-1).

Nüfusu yaşlanan ülkelerde işgücünün azalacağının beklenmesini ele alırsak, gençlerin potansiyelini daha fazla kullanmak giderek önemli bir hale gelecektir (Gomez-Salvador ve Leiner-Killinger, 2008, s. 8). 2017 yllında Dünya nüfusunun \%8.9'unu yaşlı nüfus oluşturmuştur. Türkiye, 167 ülke içerisinde en yüksek yaşlı oranına sahip ülke sıralamasında 66. Sırada yer almaktadır (TÜİK, 2018). Türkiye'de 2017 yılı itibariyle genç nüfus 11 milyon 875 bin, genç işgücü 5 milyon 146 bin kişiden oluşmaktadır. 2002 yılında genç nüfusun 15+ yaş nüfus içerisindeki payı \%26.06 iken bu oran 2006, 2010, 2014 ve 2017 yllarında sırasiyla $\% 23.73, \% 21.98, \% 20.57$ ve $\% 19.83$ seviyesine düşmüştür. Bununla birlikte, Türkiye'de 65 ve üzeri yaş nüfusun toplam nüfus içindeki payı yıllar itibariyle artış göstermiştir. 2002 yllında $\% 6,7$ olan yaşlı nüfus oranı 2006 yilında $\% 6.8,2010$ yllında $\% 7.2,2014$ yllında $\% 8$ ve 2017 yllında \%8.5 düzeyinde gerçekleşmiştir (TÜiK veri tabanı). Ylllar itibariyle genç nüfus oranının azalması ve 65 ve üzeri yaş oranının artması Türkiye'de nüfusun yaşlandığının bir göstergesidir. 
Şekil 2, Türkiye'de 2002-2017 yılları arasında gerçekleşen genç işsizlik, yetişkin işsizlik ve genç/yetişkin işsizlik oranlarını göstermektedir. Türkiye'de söz konusu yıllarda genç işsizlik oranları yetişkinlerin işsizlik oranlarının iki katından fazla düzeylerde gerçekleşmiş olup, yıllar itibariyle genç işsizlik oranlarının yüksek seviyelerinde dirençli olmaya devam ettiği görülmektedir. Genç/yetişkin işsizlik oranlarında yıllar itibariyle önemli bir değişim görülmemiştir. Diğer bir ifade ile genç işsizlik oranları yetişkin işsizlik oranlarından önemli ölçüde daha yüksek seviyelerde olmaya devam etmektedir. 2009 yılında gerçekleşen her iki işsizlik oranı da 2002-2017 yılları arasında gerçekleşen en yüksek işsizlik oranı olmuştur. Küresel finans krizinin etkisi ile birlikte genç işsizlik oranı ve yetişkin işsizlik oranı sırasıyla; 2008 yılında \%20.5 ve \%7.4 iken, 2009 yılında \%25.3 ve \%10 düzeyine yükselmiştir.

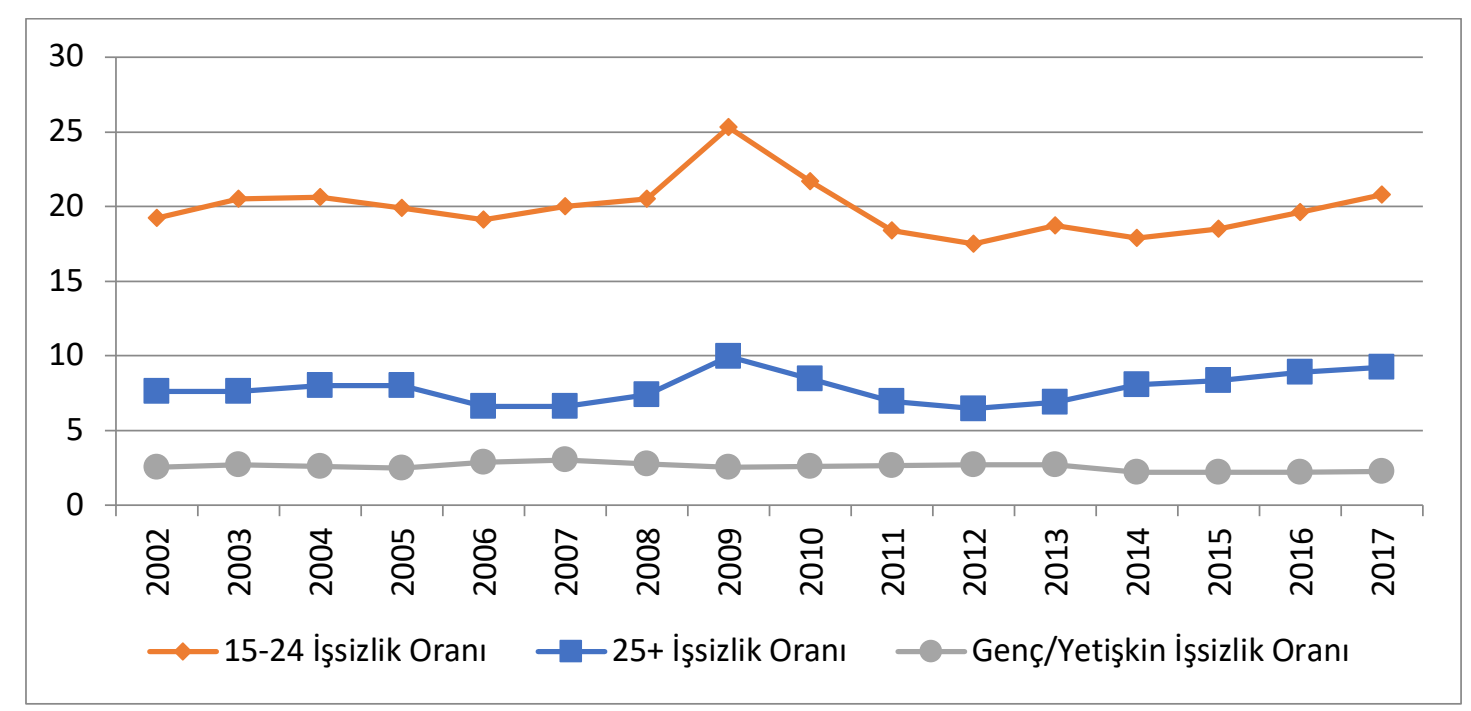

Kaynak: TÜIK ve ILOSTAT verileri kullanılarak oluşturulmuştur.

Şekil 2. Türkiye’de Genç, Yetişkin ve Genç/Yetişkin İşsizlik Oranları (\%)

\section{Türkiye'de Kadın/Erkek Genç İşsizliği, Eğitimli Genç İşsizlik ve NEET}

İşsizlik, cinsiyete ve yaşa göre değişiklik göstermektedir. Geçlerde, yetişkinlerde olduğu gibi, kadınlar işgücü piyasasında daha yüksek işsizliğe maruz kalmaktadır (Ryan, 2001, s. 41). Kadınların sadece işgücüne katılımı değil aynı zamanda iş bulmaları da erkeklere göre daha düşük seviyelerdedir. 2018 yılı itibariyle, kadınların \%6 olan global işsizlik oranı erkeklerin global işsizlik oranından \%0.8 daha fazladır. Bu durum, kadın/erkek (female to male) işsizlik oranının 1.2 olduğunu göstermektedir. Bu oranın 2021 yılına kadar gelişen ülkeler için sabit kalması, gelişmekte olan ülkeler için artması beklenmektedir (ILO, 2018, s. 7).

Şekil 3, Türkiye'de 2002-2017 yılları arasında kadın ve erkek genç işsizlik oranları ile kadın/erkek işsizlik oranlarını göstermektedir. 2002, 2003 ve 2009 yılları dışındaki yıllarda kadın genç işsizlik oranları erkek genç işsizlik oranlarının üzerinde olmuştur. Kriz yılları olan 2002 ve 2009'da kadın/erkek genç işsizlik oranı sırasıyla 0.84 ve 0.98 düzeylerinde gerçekleşmiştir. Diğer bir ifade ile ekonomik kriz dönemlerinde, erkek genç işsizlik oranı kadın genç işsizlik oranından daha yüksek düzeyde gerçekleşmiştir. 2009 yılından itibaren ise kadın ve erkek genç işsizlik oranları arasındaki fark yükselmeye başlamıştır. Kadın/erkek genç işsizlik oranı 2009 yılından itibaren artarak 2017 yılında 1.47 seviyesine yükselmiştir. 2002-2017 yılları 
arasında en yüksek düzeyine 2017 yılında ulaşan kadın/erkek genç işsizlik oranı, kadınların genç işsizlik oranının erkeklere oranla 1.5 kat daha fazla olduğunu göstermektedir.

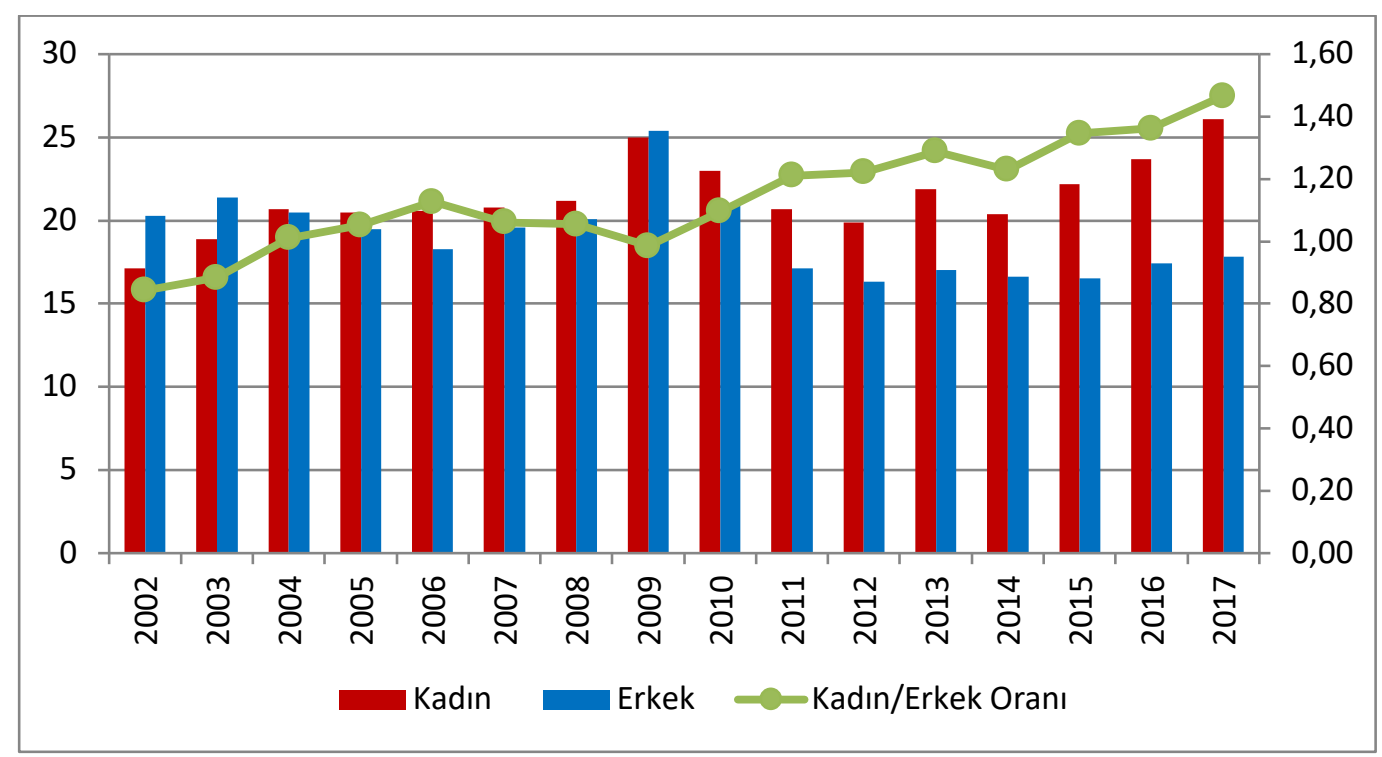

Kaynak: TÜİK veri tabanı kullanılarak oluşturulmuştur.

Şekil 3. Türkiye'de Kadın ve Erkek Genç İşsizlik Oranları (\%)

Şekil 4, Türkiye ekonomisinin çeyreklik bazda negatif büyüdüğü 2008 yılının ikinci çeyreği ile 2009 yılının birinci çeyreği arasında gerçekleşen kadın ve erkek genç ve yetişkin işsizlik oranları ile kadın/erkek genç ve yetişkin işsizlik oranlarını (să̆ eksen) göstermektedir. Ekonomik daralmanın gerçekleştiği 2008:II-2009:I dönemi arasında, erkek genç işsizlik oranlarındaki artış kadın genç işsizlik oranlarındaki artıştan daha fazla olmuştur. Kadın/erkek genç işsizlik oranları 2008:II-2009:I döneminde sırasıyla \%1.1, \%1.1, \%1 ve \%0.9 düzeyinde gerçekleşmiştir. 15-24 yaş grubu erkek işsizlik oranı, 2009 yılının birinci çeyreğinde \%29.1 ile kadın işsizlik oranının (\%27.6) üzerinde gerçekleşmiştir. Yetişkin kadın/erkek işsizlik oranı, 2008 yılının üçüncü çeyreği dışındaki dönemlerde \%0,9 seviyesinde gerçekleşmiş olup, söz konusu dönemlerde erkek işsizlik oranlarındaki artış kadın işsizlik oranlarındaki artıştan daha yüksek olmuştur. Ekonominin küçüldüğü küresel finans krizi döneminde, genel olarak erkek işsizlik oranları kadın işsizlik oranlarından daha fazla etkilenmiştir. 


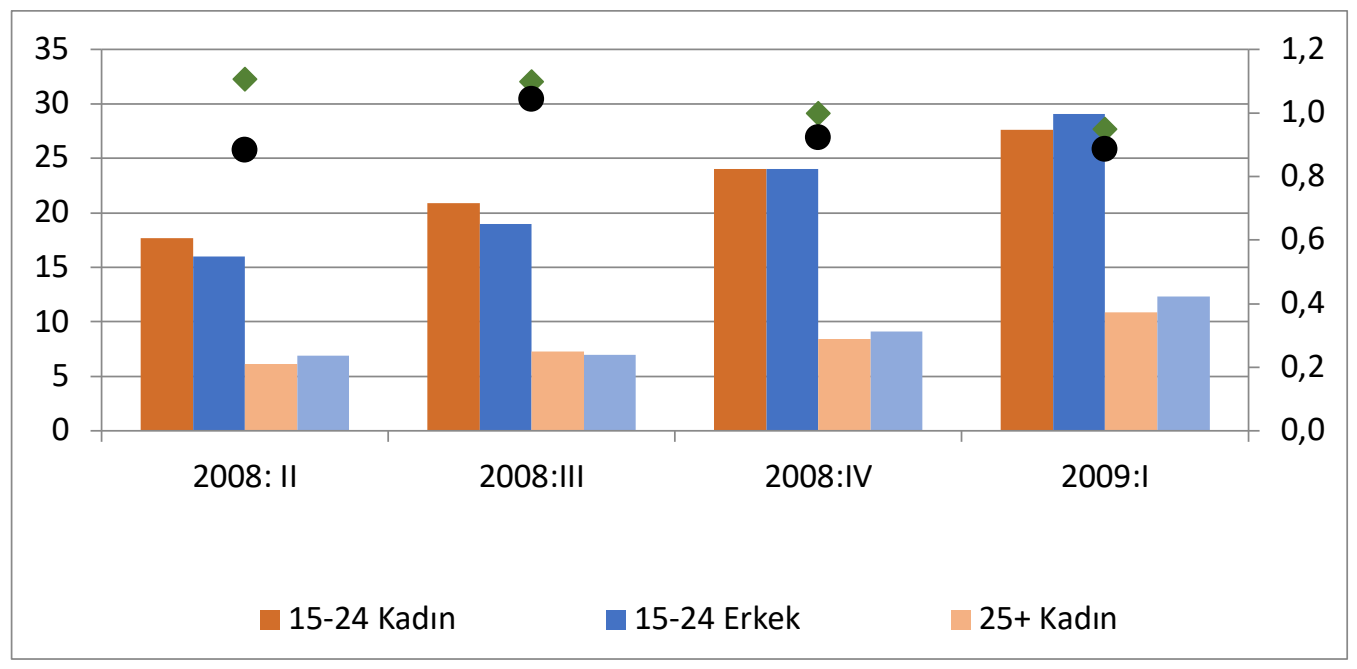

Kaynak: TÜİK ve ILOSTAT verileri kullanılarak oluşturulmuştur.

Şekil 4. 2008.II-2009:I Döneminde Gerçekleşen Kadın ve Erkek İşsizlik Oranları (\%)

Türkiye'de genç istihdam içerisinde, erkeklerin istihdamı imalat sektöründe ve özellikle inşaat sektöründe kadınlardan daha yüksektir. 2009 yılında, iktisadi faaliyet kollarına göre (18 grup), 15-24 yaş grubu toplam erkek istihdamının \%24.4'ünü imalat, \%19.1'ini toptan ve parakende ticaret, \%14.6'sını tarım, \%13.2'sini inşaat sektörlerinde; 15-24 yaş grubu kadın istihdamının \%32.9'u tarım, \%21.2'si imalat, \%17.3'ü toptan ve parakende ticaret sektörlerinde gerçekleşmiştir (TÜİK veri tabanı). Erkek genç istihdam oranlarının kadın istihdam oranlarından daha yüksek olmasına karşın, kriz dönemlerinde genç işsizlik içerisinde özellikle erkek genç işsizliğin artması, konjonktüre daha duyarlı sektörlerin (inşaat, üretim, otomotiv gibi) çoğunun istihdam açısından erkek odaklı olmasından kaynaklanmaktadır (European Commission, 2009, s. 11; Verick, 2009, s. 32; Hutengs ve Stadtmann, 2014, s. 8).

Türkiye'de 2002-2017 yılları arasında ortalama olarak; okuma yazma bilmeyen \%12.7, ilkokul mezunu \%13.7, ilköğretim mezunu \%15.4, lise dengi meslek okulu mezunu \%22.6, genel lise mezunu \%24.4 ve yükseköğretim mezunları \%31.8 genç işsizlik oranlarına sahiptir. Türkiye’de eğitim türleri içerisinde en yüksek genç işsizlik oranı yükseköğretimde görülmektedir. Şekil 5, 2002-2017 yılları arasında yükseköğretim genç işsizlik oranları ile kadın ve erkeklerde yükseköğretim genç işsizlik oranlarını göstermektedir. 


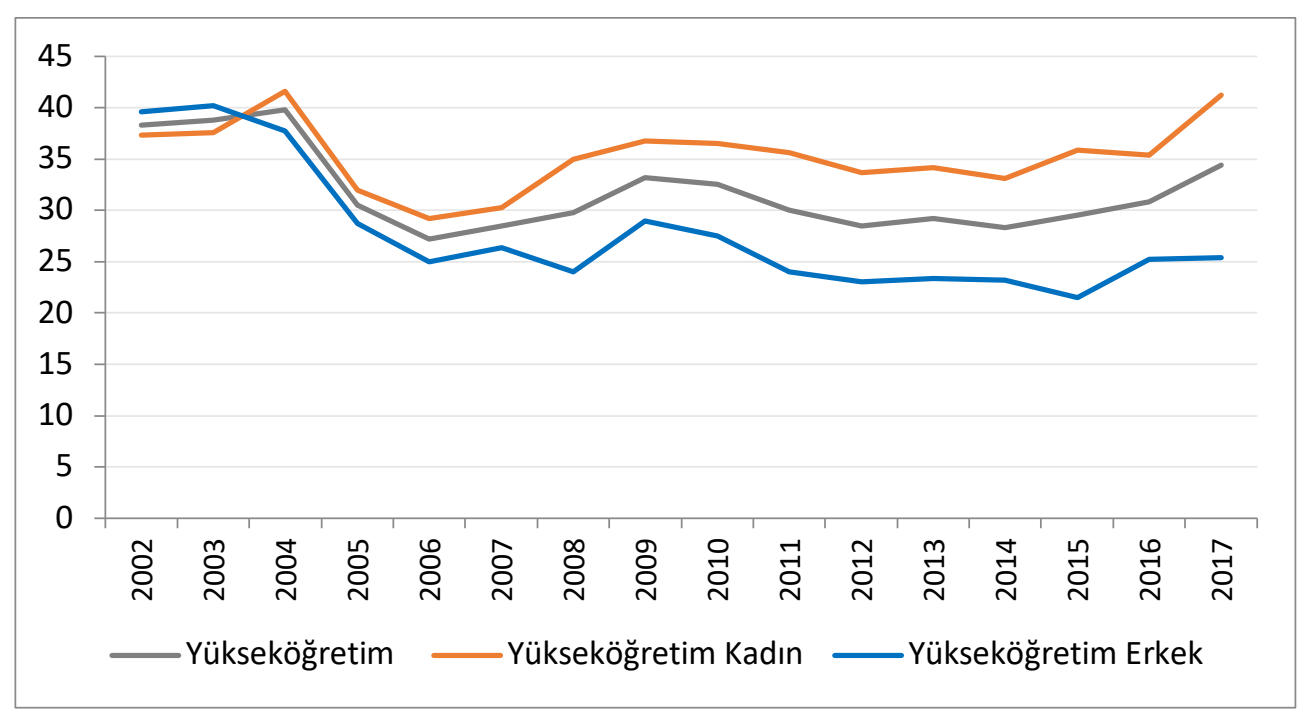

Kaynak: TÜİK veri tabanı kullanılarak oluşturulmuştur.

Şekil 5. Yükseköğretim Genç İşsizlik Oranları (\%, 2002-2017)

Şekil 5’ten görüleceği üzere, 2004 yılı ve sonrasında, kadın genç işsizlik oranları erkek genç işsizlik oranlarının üzerinde gerçekleşmiştir. Yükseköğretim mezunu genç işsizlerin oranı, 2009 yılında \%33.2'e yükselerek 2002-2016 yılları arasında en yüksek düzeye ulaşmıştır. 2008 yılında 1.46 olan yükseköğretim genç kadın/erkek işsizlik oranı 2009 yılında azalarak 1.27 düzeyinde gerçekleşmiştir. 2009 yılında, kadın genç işsizlik oranı 2009 yılında \%5.1 artarak \%36,8’e, erkek genç işsizlik oranı \%20.8 artarak \%29'a yükselmiştir. 2017 yılı itibariyle, yükseköğretim genç işsizlik oranı \%34.4, yükseköğretim mezunu erkeklerde genç işsizlik oranı \%25.4 ve yükseköğretim mezunu kadınlarda genç işsizlik oranı \%41.2 olarak gerçekleşmiştir. Yükseköğretim mezunu kadın genç işsizlik oranı ile erkek genç işsizlik oranı arasındaki fark 2016 yılından itibaren artmaya başlamıştır.

NEET (neither in employment nor in education or training), genç nüfusun ne eğitimde ne de istihdamda olanların paylarını göstermekte olup, çeşitli sebeplerle gücenmiş ya da çalışmayan işsizleri kapsamaktadır. NEET kapsamında olan gücenmiş gençler, mevcut işlerin olduğuna inanmadıklarından veya önceki araştırmalarında iş bulamadıklarından veya nerde ve nasıl iş bulacaklarını bilmediklerinden iş aramayan gençlerdir (ILO, 2017, s. 21). Tablo 2'de, 2017 yılı itibariyle Türkiye'de NEET değerlerini göstermektedir. 
Tablo 2. Türkiye'de 2017 Yılı NEET Değerleri

\begin{tabular}{|c|c|c|c|c|c|c|c|c|c|}
\hline & \multicolumn{3}{|l|}{ Toplam } & \multicolumn{3}{|l|}{ Kadın } & \multicolumn{3}{|l|}{ Erkek } \\
\hline & $\begin{array}{l}\text { Nüfus } \\
\text { (Bin } \\
\text { Kişi) }\end{array}$ & $\begin{array}{l}\text { NEET } \\
\text { (Bin } \\
\text { Kişi) }\end{array}$ & $\begin{array}{l}\text { NEET } \\
(\%)\end{array}$ & $\begin{array}{l}\text { Nüfus } \\
\text { (Bin } \\
\text { Kişi) }\end{array}$ & $\begin{array}{l}\text { NEET } \\
\text { (Bin } \\
\text { Kişi) }\end{array}$ & $\begin{array}{l}\text { NEET } \\
(\%)\end{array}$ & $\begin{array}{l}\text { Nüfus } \\
\text { (Bin } \\
\text { Kişi) }\end{array}$ & $\begin{array}{l}\text { NEET } \\
\text { (Bin } \\
\text { Kişi) }\end{array}$ & $\begin{array}{l}\text { NEET } \\
(\%)\end{array}$ \\
\hline $\begin{array}{l}\text { Okur-Yazar } \\
\text { Olmayanlar }\end{array}$ & 226 & 177 & 78,3 & 135 & 113 & 83,7 & 91 & 64 & 70,3 \\
\hline $\begin{array}{l}\text { Lise Altı } \\
\text { Eğitimliler }\end{array}$ & 7.225 & 1.558 & 21,6 & 3.494 & 1.128 & 32,3 & 3.732 & 430 & 11,5 \\
\hline Lise & 1.713 & 354 & 20,7 & 841 & 235 & 27,9 & 872 & 119 & 11,6 \\
\hline $\begin{array}{l}\text { Mesleki veya } \\
\text { Teknik Lise }\end{array}$ & 1.524 & 375 & 24,6 & 691 & 233 & 33,7 & 833 & 142 & 17 \\
\hline $\begin{array}{l}\text { Yüksek- } \\
\text { öğretim }\end{array}$ & 1.187 & 408 & 34,4 & 694 & 284 & 40,9 & 493 & 124 & 25,2 \\
\hline Toplam & 11.875 & 2.872 & 24,2 & 5.855 & 1.993 & 34 & 6.021 & 879 & 14,6 \\
\hline
\end{tabular}

2017 yılında, NEET 2 milyon 782 bin kişiden oluşmakla birlikte bu sayının \%69.39'u kadın NEET (1.993 bin kişi), \%30.61'ini erkek NEET (879 bin kişi) oluşturmakta olup, \%24.2 olan NEET oranı, kadınlarda \%34 erkeklerde \%14.6 düzeyinde gerçekleşmiştir (TÜİK veri tabanı). Kadınlarda ve erkeklerde en fazla NEET oranı okuryazar olmayanlara aittir. Okuryazar olmayanlardan sonra en yüksek NEET oranı \%34.4 ile yükseköğretim mezunlarına aittir. Toplam yükseköğretim mezunu NEET içerisinde kadınların payı \%58,5, erkeklerin payı \%41.5’tir. Yükseköğretim mezunu kadın NEET oranı \%40.9, erkek NEET oranı \%25.2 düzeyinde gerçekleşmiştir.

\section{Genç İşsizliğe iliş̧kin Literatür İncelemesi}

Genç işsizlik ile ilgili uluslararası yazında çok sayıda çalışma mevcuttur. Bu bölümde, finansal krizlerin genç işsizlik üzerindeki etkileri, genç işsizliğin makroekonomik belirleyicileri ve toplumsal sorunlar ile ilişkisini inceleyen seçilmiş ampirik çalışmalara yer verilmiştir.

Jimeno ve Rodriguez-Palenzuela (2002), 19 OECD ülkesi için 1960-1996 döneminde makroekonomik şokların genç çalışanları, yetişkinlere göre daha fazla etkilediğini ve işgücü piyasası katılığının genç işsizliği arttırdığı tespit etmişlerdir. Hutengs ve Stadtman (2014), 1992 2011 döneminde İskandinav ülkeleri için Okun katsayısını yaş ve cinsiyete göre incelemiştir. Regresyon analizi sonuçları, Okun katsayısının 15-24 yaş grubunda en yüksek düzeye ulaştığı ve bu sonucun ekonomik konjonktür hareketlerinin genç işsizlik üzerinde daha etkili olduğunu gösterdiği belirlenmiştir. Çalışmada, erkek genç işsizliğin milli gelirdeki değişimlere kadın genç işsizliğinden daha duyarlı olduğu tespit edilmiştir.

Baron (2008), Kanada'da 400 evsiz genç için işsizliğin suç üzerindeki etkilerini incelemiştir. Gençlerin parasal durumları ile ilgili memnuniyetsizlikleri arttıkça işsizliğin suç üzerindeki 
etkisinin arttı̆̆ını; yaşı daha küçük olan genç işsizlerde şiddet içerikli suçların, yaşı daha yüksek olan genç işsizlerde ilaç kullanımının daha fazla görüldüğü tespit edilmiştir. Fougère v.d. (2006), 1990-2000 döneminde Fransa'da suç ve işsizlik arasında pozitif ilişki olduğu ve genç işsizlikteki artışın suç artışlarını tetiklediğini ortaya koymuştur.

Choudhry vd. (2012), 75 ülkede finansal krizlerin genç işsizlik üzerindeki etkilerini 1980-2005 dönemi için panel veri analizi ile araştırmıştır. Finansal krizlerin genç işsizlik üzerinde pozitif güçlü etkileri olduğu, bu etkilerin yüksek gelir grubundaki ülkelerde daha önemli olduğu, finansal krizlerin genç işsizlik üzerindeki en olumsuz etkisinin finansal krizden sonraki ikinci ve üçüncü yılda görüldüğü sonucuna varılmıştır. Verick (2009), İspanya, Norveç, Finlandiya, İsveç ve Japonya'da yaşanmış olan finansal krizleri ve son yaşanan global finansal krizin yol açtığı işsizlikten en çok gençlerin (daha çok 15-24 yaş grubu erkeklerin) etkilendiğini ve krizden sonra ekonomik büyümeden sonra da genç işsizliğin dirençli kaldığını tespit etmiştir. Bruno vd. (2017), OECD ülkelerinde 1981-2009 dönemi için dinamik panel veri analizini kullanarak, finansal krizlerin genç işsizlik ve işsizlik üzerindeki etkilerini incelemiştir. Analiz sonuçları, finansal krizlerin genç işsizlik üzerinde işsizlik üzerindeki etkilerinden kısa dönemde 1.9 kat, uzun dönemde 1.5-1.6 kat daha yüksek pozitif etkisi olduğunu göstermiştir.

Bruno vd. (2014), Euro bölgesinde küresel finans krizinin NEET ve genç işsizlik üzerindeki etkileri GMM ve dinamik panel veri yöntemi ile incelemiştir. Kriz yllarında NEET oranlarının büyümeye karşı gösterdiği direncin arttığını, 2009 yılı başlangıcında NEET oranlarının önemli ölçüde büyümeye daha az duyarlı olduğu, erkek NEET oranının kadın NEET oranına göre milli gelire daha fazla duyarlı olduğu tespit edilmiştir.

Caporale ve Alana (2014), 1980-2005 dönemi için 15 Avrupa ülkesinde genç işsizliğin milli gelir ve enflasyon ile uzun dönem ilişkisi olduğu bulunmuştur. 15 Avrupa ülkesinde de genç işsizliğin oldukça dirençli (persistent) olduğu tespit edilmiştir. Tomić (2017), 2002-2014 dönemi için Euro-28 üye ülkeleri için panel veri analizi ile düşük milli gelir büyümesi, düşük inşaat payı ve yüksek kamu borcuna sahip ekonomilerde genç işsizliğin daha yüksek olduğunu tespit etmiştir.

Göçer ve Erdal (2015), 2006-2012 yllarında 18 Avrupa ülkesi (birinci grup) ve 1996-2012 yllarında 10 Avrupa ülkesi için (ikinci grup) yeni panel veri analizi ve eşbütünleşme testlerini kullanarak Okun kuralı çerçevesinde genç işsizlik ve ekonomik büyüme arasındaki ilişkiyi incelemiştir. Analiz sonuçlarına göre, ekonomik büyümedeki 1 puanlık artış birinci gruptaki genç işsizliği \%1.13, ikinci gruptaki genç işsizliği \%2.06 azalttığını göstermiştir.

Türkiye'de genç işsizlik ile ilgili sınırlı sayıda çalışma yapılmıştır. Bu çalışmalarda, genç işsizlik ile ekonomik büyüme, eğitim, verimlilik, enflasyon, doğrudan yabancı yatırımlar, ithalat ve toplumsal sorunlar arasında ilişki araştırılmıştır.

2005-2010 dönemi için VAR modeli ve Johansen (1988) eşbütünleşme testinin kullanıldığı Kabaklarlı vd. (2011) çalışmasında, GSYH ve kişi başına yatırımların genç işsizliği negatif yönde, enflasyon ve verimliliğin (kişi başına hasıla) genç işsizliği pozitif yönde etkilediği tespit edilmiştir. Çondur ve Bölükbaş (2014), 2000:Q1-2010:Q4 dönemi için Granger nedensellik testini kullanarak genç işsizlikten GSYİH’a doğru ve ÜFE'den genç işsizliğe doğru nedensellik ilişkisi tespit etmiştir. 
Yavuzaslan vd. (2017), yapısal kırılmalı birim kök testi ile histeri hipotezinin geçerliliğini 2005:01-2017:02 döneminde genç işsizlik oranları kapsamında incelemiştir. 2008 yılının ikinci ve dokuzuncu ayı ile 2010 yılının onuncu ayında yapısal kırılmalar yaşanmasının Türkiye'de söz konusu araştırma dönemi için genç işsizlik histerisinin geçerli olduğu sonucuna ulaşılmıştır.

Sayın (2011), 1988-2010 döneminde eğitim ve büyümenin genç işsizliğe etkisini VAR modeli ile incelemiştir. Ampirik sonuçlar, genç işsizlikten ortaöğretim okullaşma oranına doğru bir nedensellik ilişkisinin olduğu ve genç işsizliği uzun dönemde kendisinden sonra en çok büyüme ve yükseköğretim okullaşma oranının etkilediğini ortaya koymuştur. İzgi (2012), 1988-2008 yılları için eğitimli ve eğitimsiz genç işsiz grupları arasındaki ilişkiyi t testi ile incelemiştir. T testi sonuçları, eğitimli ve eğitimsiz gruplar arasında anlamlı bir farklılık olduğunu göstermiştir. Çondur ve Şimşir (2017), 1991-2016 dönemi için en küçük kareler yöntemini kullanarak, eğitim harcamaları/GSYH oranındaki 1 birimlik bir artışın genç işsizlik oranında 2.27 birimlik bir artışa; büyüme oranındaki 1 birimlik bir artışın, genç işsizlik oranında 0.21 birimlik bir azalmaya yol açtı̆̆

Günaydın ve Çetin (2015), 1988-2013 dönemi için uzun dönem ARDL modeli sonuçlarına göre kişi başına reel gelir, ticari açıklık ve doğrudan yabancı sermaye ile genç işsizlik arasında negatif ve istatistiki olarak anlamlı bir ilişki tespit ederken, enflasyon ile genç işsizlik arasında uzun dönem ilişkisi bulunamamıştır. Granger nedensellik sonuçları, genç işsizlik ile doğrudan yabancı yatırımlar arasında uzun dönemde çift yönlü bir nedensellik ve uzun dönemde kişi başına reel gelir, ticari açıklık ve enflasyondan genç işsizliğe doğru bir uzun dönem ilişkisi tespit edilmiştir.

Aslan ve Yamak (2015), genç işsizlik ve büyüme ilişkisini 2000.Q1-2013.Q4 dönemi için VAR modeli ile incelemiştir. Genç işsizlik ve büyüme arasında negatif bir ilişkinin bulunduğu çalışmada, Granger nedensellik testi sonuçları büyüme oranından genç işsizlik oranına doğru tek yönlü bir nedensellik olduğunu göstermiştir. Karahan ve Uslu (2017), 2005.Q1-2016.Q2 dönemi için Kalman filtresi yöntemini kullanarak, ekonomik büyümenin genç işsizlik üzerindeki etkisinin küresel finans krizi döneminde düştügünü tespit etmiştir.

Cenger ve Çütçü (2018), 2005:01-2017:03 dönemi için genç işsizlik ile ithalat arasındaki ilişkiyi Engle-Granger eşbütünleşme testi, Granger nedensellik testi ve Toda-Yamamoto nedensellik testi ile incelemiştir. Eşbütünleşme analizi sonuçları, genç işsizlik ve ithalat arasında uzun dönemli bir ilişkinin olmadığını; her iki nedensellik analiz sonuçları ise genç işsizlik ile ithalat arasında bir nedensellik ilişkisinin bulunmadığını göstermiştir.

Özer ve Topal (2017), genç işsizliğin toplumsal sorunlar üzerindeki etkilerini 2004-2016 dönemi için panel korelasyon ve panel nedensellik analizleri ile incelemiştir. Çalışmada, genç işsizlik ile suç, göç, intihar ve boşanma olguları arasında pozitif ve istatistiksel olarak anlamlı bir ilişki olduğu, genç işsizliğin suç, göç, intihar ve boşanma sorunlarını daha da derinleştirdiği ve genç işsizliğin göç, intihar, boşanma gibi toplumsal sorunların bir nedeni olduğunu sonucuna ulaşılmıştır. 


\section{Veri Seti ve Yöntem}

2006:Q1-2017:Q4 dönemini kapsayan çalışmada, genç (15-24) işsizlik oranı (\%) ve mevsim etkilerinden arındırılmış yıllık GSYH değişim oran (\%) değişkenleri TÜİK veri tabanından, yetişkin (25+) işsizlik oranı (\%) değişkeni ILOSTAT veri tabanından elde edilmiştir. Genç işsizlik ve yetişkin işsizlik oranları Tramo-Seats yöntemi ile mevsim etkilerinden arındırılıp analize dahil edilmiştir. Ampirik analizde kullanılan genç işsizlik oranları, yetişkin işsizlik oranları ve ekonomik büyüme oranları sırasıyla şu simgelerler ifade edilmiştir: UNY, UNA, Y.

Ampirik analizde ilk olarak serilerin durağanlıkları ADF (Augmented Dickey-Fuller), PP (Phillips-Peron) ve Ng-Perron testleriyle incelenmiştir. Durağanlık analizinden sonra, genç işsizlik-ekonomik büyüme ve yetişkin işsizlik-ekonomik büyüme arasındaki eşbütünleşme ilişkisinin varlığı Pesaran vd. (2001) tarafından geliştirilen Sınır testi yaklaşımıyla araştırılmıştır. Eşbütünleşme ilişkisinden sonra seriler arasındaki uzun ve kısa dönemdeki statik ilişki ARDL (Autoregressive Distributed Lag) modeli ile incelenmiştir. Son olarak, ekonomik büyümenin genç işsizlik ve yetişkin işsizlik üzerindeki dinamik etkileri Kalman filtresi yöntemi ile analiz edilmiştir.

\section{Durağanlık Analizi}

Uygulamalı analizde, ilk olarak serilerin durağanlık özellikleri ADF, PP ve Ng-Perron testleri kullanılarak incelenmiştir. Serilerin düzey değerleri için yapılan birim kök testlerinde sabitli ve trendli model, birinci farkları alınarak yapılan söz konusu testlerde sadece sabit terim içeren model alınmıştır. Durağanlık test sonuçları Tablo 3’te sunulmaktadır.

\section{Tablo 3. Durağanlık Test Sonuçları}

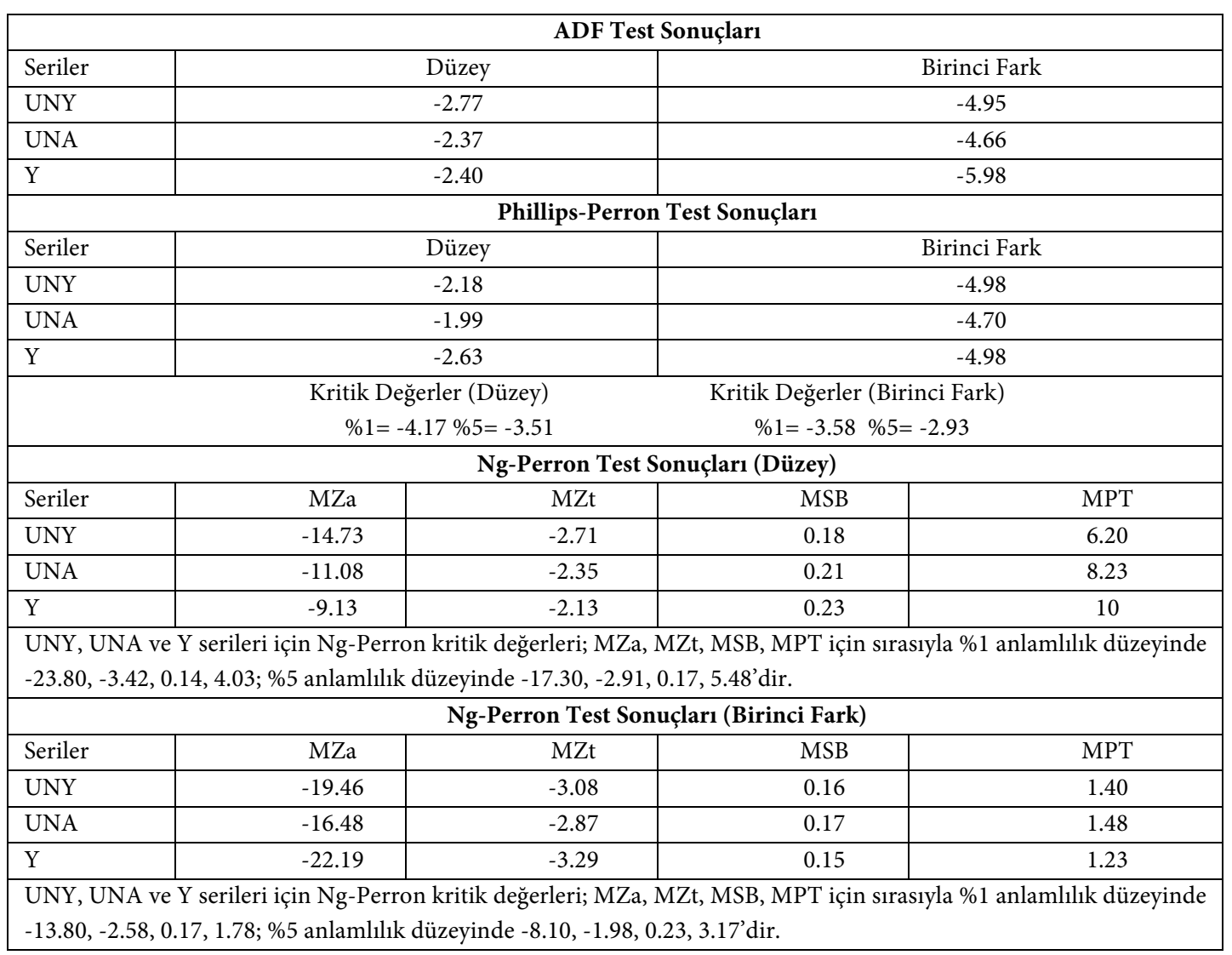


ADF ve PP testinde temel hipotez serinin birim kök içerdiği biçiminde kurulmaktadır. Tablo 3 ’te görüleceği üzere, $\% 1$ ve $\% 5$ anlam düzeylerinde UNY, UNA ve Y serileri için ADF ve PP testlerine göre düzey halde hesaplanan değerler tablo kritik değerlerden mutlak değer olarak küçük; birinci farklarda hesaplanan değerler tablo kritik değerlerden mutlak değer olarak büyük bulunmuştur. Diğer bir ifade ile ADF ve PP testleri için temel hipotez her iki seri için de reddedilememiştir.

Ng-Perron testi için $\mathrm{MZ}_{\mathrm{a}}$ ve $M Z_{\mathrm{t}}$ testlerinde temel hipotez serinin birim kök içerdiği; MSB ve MPT testlerinde temel hipotez serinin durağan olduğu şeklinde kurulmaktadır. Tüm seriler için \%1 ve \%5 anlam düzeylerinde; $M_{\mathrm{a}}$ ve $M Z_{\mathrm{t}}$ testlerine göre düzey halde hesaplanan değerler tablo kritik değerlerden mutlak değer olarak küçük; MSB ve MPT testlerine göre hesaplanan değerler tablo kritik değerlerden büyük bulunmuştur. UNY, UNA ve Y serileri için her iki anlam düzeyinde birinci farklarda, $\mathrm{MZ}_{\mathrm{a}}$ ve $\mathrm{MZ}_{\mathrm{t}}$ testlerine göre hesaplanan değerler tablo kritik değerlerden mutlak değer olarak büyük bulunmuştur. Birinci farklarda, UNY ve Y serileri için MSB testine göre hesaplanan değerler her iki anlam düzeyinde de, UNA serisi için \%5 anlamlılık düzeyinde tablo kritik değerlerden küçük; tüm seriler için MZT testine göre hesaplanan değerler her iki anlam düzeyinde tablo kritik değerlerden küçük bulunmuştur.

Özetle, durağanlık analizi için kullanılan ADF, PP ve Ng-Perron test sonuçlarına göre UNY, UNA ve Y serilerinin birinci dereceden durağan oldukları (I(1)) oldukları bulunmuştur.

\section{Eşbütünleşme Analizi}

Durağanlık analizinden sonra, genç işsizlik ve büyüme serileri arasındaki eşbütünleşme ilişkisi Peseran vd.(2001) tarafından geliştirilen Sınır Testi yaklaşımıyla araştırılmıştır. Serilerin durağanlık özelliklerine bakılmaksızın uygulanabilmesi', kısıtlanmamış hata düzelme modelinin (UECM) iki aşamalı Engle-Granger yönteminden daha iyi istatistiksel özelliklere sahip olması ve düşük sayıda gözleme sahip çalışmalarda uygulanabilir olması, sınır testi yaklaşımının Engle ve Granger (1987), Johansen (1988, 1995), Johansen ve Juselius (1990) gibi alternatif eşbütünleşme testlerine göre sağladığı avantajlardır (Narayan ve Narayan, 2005, s. 429, Uslu ve Karahan, 2016, s. 677).

Çalışmamızda, Sınır testi için oluşturulan kısıtlanmamış hata düzeltme modelinin (UECM) çalışmamıza uyarlanmış hali (1) numaralı denklemde (t: trend değişkeni; p: gecikme sayısı) gösterilmektedir.

$$
\begin{gathered}
\Delta \mathrm{UNY}_{t}=a_{0}+a_{1 t+} \sum_{i=1}^{p} a_{2 i} \Delta U N \mathrm{Y}_{t-i}+\sum_{i=0}^{p} a_{3 i} \Delta \mathrm{Y}_{t-i} \\
+a_{4} Y U N \mathrm{Y}_{t-1}+a_{5} \mathrm{Y}_{t-1}+u_{t}
\end{gathered}
$$

\footnotetext{
${ }^{4}$ Pesaran vd. (2001) tarafından hesaplanan F istatistikleri, serilerin I(2) olması durumunda geçersiz olmaktadır. Durağanlık testleri, yanıltıcı sonuçlardan kaçınmak için değişkenlerin ikinci dereceden durağan (I(2)) olmadıklarını garantilemektedir (Frimpong ve Oteng-Abeyie, 2006, s. 9).
} 


$$
\begin{gathered}
\Delta \mathrm{UN} A_{t}=a_{0}+a_{1 t+} \sum_{i=1}^{p} a_{2 i} \Delta U N \mathrm{~A}_{t-i}+\sum_{i=0}^{p} a_{3 i} \Delta \mathrm{Y}_{t-i} \\
+a_{4} Y U N A_{t-1}+a_{5} \mathrm{Y}_{t-1}+u_{t}
\end{gathered}
$$

Eşbütünleşme ilişkisinin varlığının test edilmesi için bağımlı ve bağımsız değişkenlerin birinci dönem gecikmelerine $\mathrm{H}_{0}: \alpha_{4}=\alpha_{5}=0$ (eşbütünleşme yoktur) şeklinde kurulan $\mathrm{F}$ testi yapılır. Hesaplanan F istatistiği Pesaran vd. (2001)'deki tablo alt ve üst kritik değerleri ile karşılaştırılır. Eğer hesaplanan F istatistiği Pesaran alt kritik değerinden küçükse, seriler arasında eşbütünleşme ilişkisi yoktur. Hesaplanan F istatistiği Pesaran üst kritik değerin üzerindeyse, seriler arasında eşbütünleşme ilişkisi vardır (Karagöl vd., 2007, s. 76). UECM modellerinden hesaplanan F testleri ve tablo kritik değerleri Tablo 4'te gösterilmektedir.

Tablo 4. Sınır Testi Sonuçları

\begin{tabular}{l|l|l|l|l|}
\hline \multirow{2}{*}{ Seriler } & \multirow{2}{*}{ K } & \multirow{2}{*}{ F istatistiği } & $\% 5$ anlamlılık düzeyindeki kritik değerler \\
\cline { 3 - 5 } & & & Alt Sınır & Üst Sınır \\
\hline UNY & 1 & 5.02 & \multirow{2}{*}{3.62} & 4.16 \\
\hline UNA & 1 & 6.58 & \multicolumn{3}{|c|}{} \\
\hline
\end{tabular}
K değeri; (1) numaralı denklemdeki bağımsız değişken sayısıdır. Kritik değerler Paseran vd. (2001: s.
300)'deki Tablo CI(ii)'den alınmıştır.

UECM modelinden hesaplanan F istatistik değeri UNY serisi için 5.02, UNA serisi için 6.58 olarak hesaplanmıştır. Hesaplanan F istatistikleri, \%5 anlam düzeyinde Pesaran'ın üst kritik değerinden büyük olduğu için temel hipotez her iki seri için de reddedilmiştir. Sınır testi sonuçları, büyümenin her iki işsizlik ile eşbütünleşme ilişkisinin olduğunu göstermiştir.

\section{ARDL Modeli}

Seriler arasında eşbütünleşme ilişkisi tespit edildikten sonra, büyümenin genç işsizlik ve yetişkin işsizlik arasındaki uzun ve kısa dönemdeki statik ilişkilerini belirlemek için ARDL (Autoregressive Distributed Lag) modelleri kurulmuştur.

Genç işsizlik-büyüme arasındaki ve yetişkin işsizlik-büyüme arasındaki uzun dönem ilişkinin araştırılması için ARDL modelinin çalışmamıza uyarlanmış hali sırasıyla (2) ve (4) numaralı denklemlerde; söz konusu seriler arasındaki kısa dönem ilişkinin araştırılması için ARDL modelinin çalışmamıza uyarlanmış hali, $\mathrm{m}$ ve $\mathrm{n}$ gecikme değerlerini göstermek üzere, sırasıyla (3) ve (5) numaralı denklemlerde gösterilmektedir.

$$
\begin{aligned}
\mathrm{UNY}_{t} & =a_{0}+\sum_{i=1}^{m} a_{1 i} \mathrm{UNY}_{t-i}+\sum_{i=0}^{n} a_{2 i} \mathrm{Y}_{t-i}+u_{t} \\
\Delta \mathrm{UNY}_{t} & =a_{0}+a_{1} \mathrm{ECM}_{t-1}+\sum_{i=1}^{m} a_{2 i} \Delta \mathrm{UNY}_{t-i}+\sum_{i=0}^{n} a_{3 i} \Delta \mathrm{Y}_{t-i}+u_{t}
\end{aligned}
$$




$$
\begin{aligned}
\mathrm{UNA}_{t} & =a_{0}+\sum_{i=1}^{m} a_{1 i} \mathrm{UNA}_{t-i}+\sum_{i=0}^{n} a_{2 i} \mathrm{Y}_{t-i}+u_{t} \\
\Delta \mathrm{UNA}_{t} & =a_{0}+a_{1} \mathrm{ECM}_{t-1}+\sum_{i=1}^{m} a_{2 i} \Delta \mathrm{UNA}_{t-i}+\sum_{i=0}^{n} a_{3 i} \Delta \mathrm{Y}_{t-i}+u_{t}
\end{aligned}
$$

Uzun dönem ilişkisinden elde edilen hata terimleri serisinin bir dönem gecikmeli değeri olan (3) ve (5) numaralı denklemlerdeki $\mathrm{ECM}_{\mathrm{t}-1} 1$ değişkeninin katsayısı kısa dönemdeki dengesizliğin ne kadarının uzun dönemde düzeltileceğini göstermektedir (Karagöl vd., 2007, s. 78). ARDL modelinde gecikme sayılarının belirlenmesi için Akaike bilgi kriterinden yararlanılmıştır. UNY serisi için ARDL $(1,3)$ modeli ve UNA serisi için ARDL $(1,0)$ modeli tahmin sonuçları Tablo 5 'de sunulmaktadır

\begin{tabular}{|c|c|c|}
\hline \multicolumn{3}{|c|}{ UNY Serisi İçin ARDL $(1,3)$ Modelinin Tahmin Sonuçları } \\
\hline Değişkenler & Katsayı & t istatistiği \\
\hline UNY (-1) & 0.709600 & $7.478904^{*}$ \\
\hline $\mathrm{Y}$ & -0.109362 & $-2.404517^{*}$ \\
\hline $\mathrm{Y}(-1)$ & -0.187933 & $-2.998521^{\star}$ \\
\hline $\mathrm{Y}(-2)$ & 0.180732 & $2.763224^{*}$ \\
\hline $\mathrm{Y}(-3)$ & -0.083740 & $-1.769522^{\star *}$ \\
\hline $\mathrm{C}$ & 6.802086 & $3.241241^{*}$ \\
\hline \multicolumn{3}{|c|}{ ARDL $(1,3)$ Modeli Tanısal Denetim Sonuçları } \\
\hline $\mathrm{X}^{2} \mathrm{BG}$ & \multicolumn{2}{|l|}{$0.936241[0.4012]$} \\
\hline $\mathrm{X}^{2} \mathrm{WHITE}$ & \multicolumn{2}{|l|}{$2.587253[0.1152]$} \\
\hline $\mathrm{X}^{2} \mathrm{RAMSEY}$ & \multicolumn{2}{|l|}{$1.641638[0.2079]$} \\
\hline \multicolumn{3}{|c|}{ ARDL $(1,3)$ Modelinin Uzun Dönem Katsayıları } \\
\hline $\mathrm{Y}$ & -0.689752 & $-4.683708^{*}$ \\
\hline $\mathrm{C}$ & 23.423181 & $26.759509^{*}$ \\
\hline \multicolumn{3}{|c|}{ ARDL $(1,3)$ Yaklaşımına Dayalı Hata Düzeltme Modeli Sonuçları } \\
\hline $\mathrm{D}(\mathrm{Y})$ & -0.109362 & $-2.698064^{\star \star}$ \\
\hline $\operatorname{ECM}(-1)$ & -0.290400 & $-3.978211^{*}$ \\
\hline \multicolumn{3}{|c|}{ UNA Serisi İçin ARDL $(1,0)$ Modelinin Tahmin Sonuçları } \\
\hline Değişkenler & Katsayı & t istatistiği \\
\hline UNA $(-1)$ & 0.820974 & $17.22807^{*}$ \\
\hline $\mathrm{Y}$ & -0.074625 & $-6.273038^{*}$ \\
\hline $\mathrm{C}$ & 1.869781 & $4.527282^{*}$ \\
\hline \multicolumn{3}{|c|}{ ARDL $(1,0)$ Modeli Tanısal Denetim Sonuçları } \\
\hline $\mathrm{X}^{2} \mathrm{BG}$ & \multicolumn{2}{|l|}{$0.066444[0.9358]$} \\
\hline $\mathrm{X}^{2} \mathrm{WHITE}$ & \multicolumn{2}{|l|}{$1.282673[0.2635]$} \\
\hline $\mathrm{X}^{2} \mathrm{RAMSEY}$ & \multicolumn{2}{|l|}{$1.328639[0.1910]$} \\
\hline \multicolumn{3}{|c|}{ ARDL $(1,0)$ Modelinin Uzun Dönem Katsayıları } \\
\hline $\mathrm{Y}$ & -0.416838 & $-3.727447^{*}$ \\
\hline $\mathrm{C}$ & 10.444192 & $15.209612^{*}$ \\
\hline \multicolumn{3}{|c|}{ ARDL $(1,0)$ Yaklaşımına Dayalı Hata Düzeltme Modeli Sonuçları } \\
\hline $\mathrm{D}(\mathrm{Y})$ & -0.076819 & $-4.473776^{\star}$ \\
\hline $\operatorname{ECM}(-1)$ & -0.176006 & $-5.460378^{*}$ \\
\hline
\end{tabular}

Tablo 5. ARDL Modelleri Tahmin Sonuçları 
ARDL $(1,3)$ modeli sonuçlarına göre; uzun dönemde büyümenin genç işsizlik üzerinde negatif ve istatistiksel olarak anlamlı bir biçimde etkilediğini göstermektedir. Uzun dönem ARDL modeli sonuçlarına göre, uzun dönemde ekonomik büyümedeki \%1’lik artış, genç işsizlik oranında \%0.69 oranında azalışa yol açmaktadır. Kısa dönemli hata düzeltme sonuçları, büyüme ve genç işsizlik oranı arasında kısa dönemde de negatif ve istatistiksel olarak anlamlı bir ilişki olduğunu göstermektedir. Hata düzeltme modeline sonuçlarına göre, yıllık GSYH değişim oranı büyümesindeki 1 puanlık artış, genç işsizlik büyüme oranında -0.11 puanlık bir azalışa yol açmaktadır. Modelde -0.29 bulunan hata düzeltme değişkeninin katsayısı $\left(\mathrm{ECM}_{\mathrm{t}-1}\right)$, beklendiği gibi negatif ve istatistiksel olarak anlamlı çıkmıştır. Bu katsayı, kısa dönemde uzun dönem dengeden bir sapma olması halinde, sistemin yaklaşık 3.4 çeyrekte dengeye ulaşacağını göstermektedir.

ARDL $(1,0)$ modeli sonuçlarına göre; uzun ve kısa dönemde büyümenin yetişkin işsizlik üzerinde negatif ve istatistiksel olarak anlamlı bir biçimde etkilediğini göstermektedir. Uzun dönem ARDL modeli sonuçlarına göre, uzun dönemde ekonomik büyümedeki \%1'lik artış, yetişkin işsizlik oranında \%0.42 oranında azalışa yol açmaktadır. Hata düzeltme modeli sonuçları, yıllık GSYH değişim oranı büyümesindeki 1 puanlık artışın, yetişkin işsizlik büyüme oranında -0.08 puanlık bir azalışa yol açmaktadır. ECM $_{\mathrm{t}-1}$ değişkeni katsayısı modelde -0.18 olarak bulunmuştur. Buna göre, kısa dönemde uzun dönem dengeden bir sapma olması halinde sistem yaklaşık 5,5 çeyrekte dengeye gelmektedir.

\section{Kalman Filtresi}

Seriler arasında uzun dönemli ilişki bulunduktan sonra, ekonomik büyümenin genç işsizlik ve yetişkin işsizlik üzerindeki dinamik etkilerini tespit etmek amacıyla Kalman Filtresi tekniği kullanılmıştır. Kalman filtresi tekniği, dinamik bir sistemde verilen gözlemleri kullanarak gözlenemeyen değişkenleri en az hata ile tahmin eden indirgemeli bir tahmin algoritmasıdır (Ertuğrul, 2011, s. 66).

Çalışmada genç işsizlik oranı ve yetişkin işsizlik oranı ekonomik büyüme ile açıklanmış olup, kullanılan Kalman Filtresi spesifikasyonları (6), (7), (8) ve (9) numaralı denklemlerde gösterilmiştir. Söz konusu denklemlerde yer alan $v_{\mathrm{i}, \mathrm{t}}$ ve $\varepsilon_{\mathrm{t}}$ beyaz gürültülü (white noise) stokastik süreci ifade etmektedir (Ertuğrul, 2012, s. 120).

$$
\begin{gathered}
\mathrm{UNY}_{\mathrm{t}}=\alpha_{0}+\alpha_{1, \mathrm{t}} \mathrm{Y}+\varepsilon_{\mathrm{t}} \\
\alpha_{1, \mathrm{t}}=\alpha_{1, \mathrm{t}-1+} v_{\mathrm{i}, \mathrm{t}} \\
\mathrm{UNA}_{\mathrm{t}}=\alpha_{0}+\alpha_{1, \mathrm{t}} \mathrm{Y}+\varepsilon_{\mathrm{t}} \\
\alpha_{1, \mathrm{t}}=\alpha_{1, \mathrm{t}-1+} v_{\mathrm{i}, \mathrm{t}}
\end{gathered}
$$

(7) ve (8) numaralı eşitliklerde yer alan $\alpha_{1, t}$ katsayıları, sırasıyla genç işsizlik-ekonomik büyüme ve yetişkin işsizlik-ekonomik büyüme arasındaki dinamik ilişkinin analiz edilmesi için tahmin edilen zamana göre değişen parametre katsayılarıdır. Genç işsizlik ve ekonomik büyüme arasındaki dinamik ilişkinin analiz edilmesi için tahmin edilen zamana göre değişen parametre tahmin sonuçları Şekil 6'da; ekonomik büyümenin yetişkin işsizlik üzerindeki etkisini gösteren zamana göre değişen parametre tahmin sonuçları Şekil 6'da sunulmaktadır. Zamana göre değişen parametre tahminleri (TVP) belli bir gözlem sonra sağlıklı sonuçlar vermesi nedeniyle 
2006:Q1-2006:Q4 dönemi şekillerden çıkarılmış olup, şekiller 2007:Q1-2017:4 dönemini ifade etmektedir. TVP tahmin sonuçları, dinamik katsayının genç işsizlik serisi için -0.30, yetişkin işsizlik serisi için -0.13 olduğunu göstermiştir.

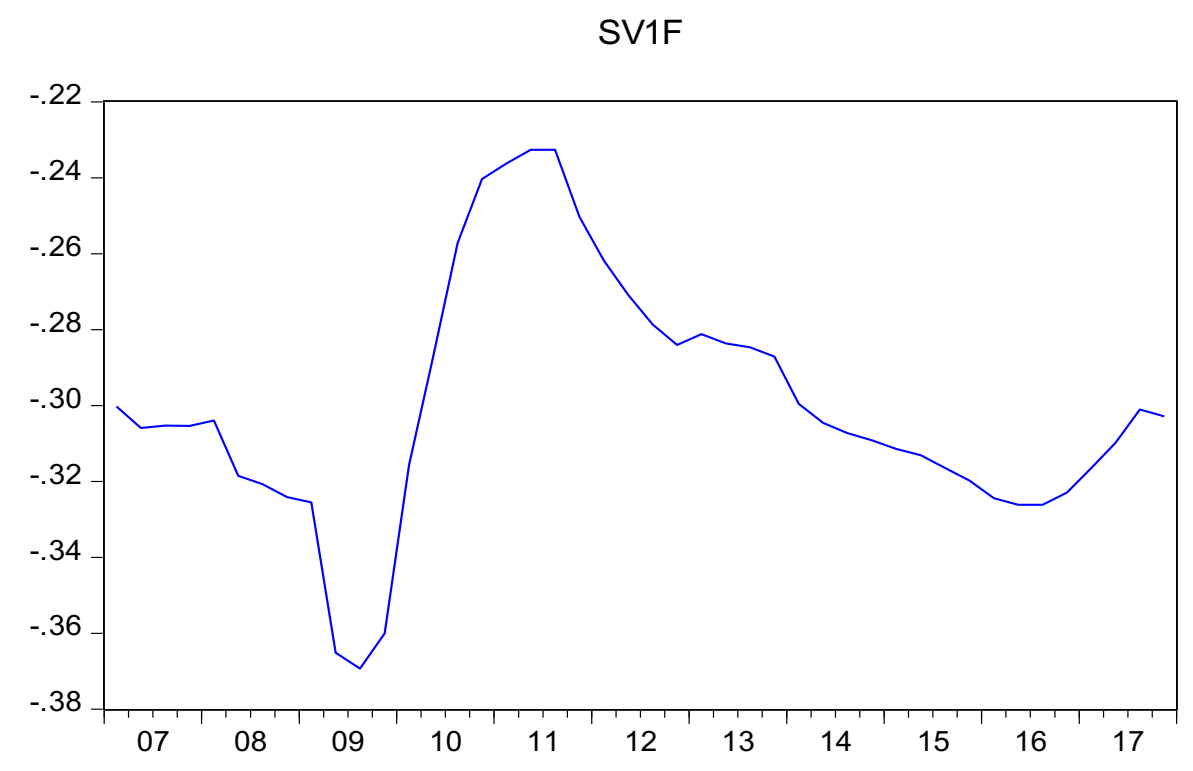

Şekil 6. UNY Katsayısı İçin Kalman Filtresi Tahmin Sonuçları

Şekil 6'da yer alan Kalman filtresi tahmin sonuçları, ekonomik büyümenin genç işsizlik üzerinde negatif etkiye sahip olduğunu göstermiştir. Diğer bir ifade ile ekonomik büyüme arttığı zaman genç işsizlik oranı azalmakta ya da ekonomik büyüme azaldığı zaman genç işsizlik oranı artmaktadır. Şekil 6 incelendiğinde, büyümenin genç işsizlik üzerindeki etkisinin küresel finans krizi döneminin etkilerinin olduğu 2008:Q1-2009:Q3 dönemi arasında arttığ1 görülmektedir. Söz konusu etkide, 2009 yılının birinci çeyreği ile üçüncü çeyreği arasında en yüksek artış gerçekleşmiştir. TVP sonuçları, ekonominin negatif büyüme gösterdiği 2009:Q12009:Q3 döneminde, ekonomik daralmanın genç işsizlik üzerindeki negatif etkisinde artış olduğunu göstermiştir. Ekonomik büyümenin gerçekleştiği 2009:Q3-2010:Q3 dönemi arasında, ekonomik büyümenin genç işsizlik üzerindeki etkisinin azalmıştır. Diğer bir ifade ile küresel finans krizi sonrasında yaşanan ekonomik büyüme oranlarının genç işsizlik oranlarını düşürmedeki etkisi 2010 yılının üçüncü çeyreğine kadar azalmıştır. Model sonuçlarına göre, bu tarihten itibaren söz konusu etki zaman içerisinde genel olarak artmakla birlikte son dört çeyrekte etkinin tekrar azalmaya başladığı görülmektedir. 


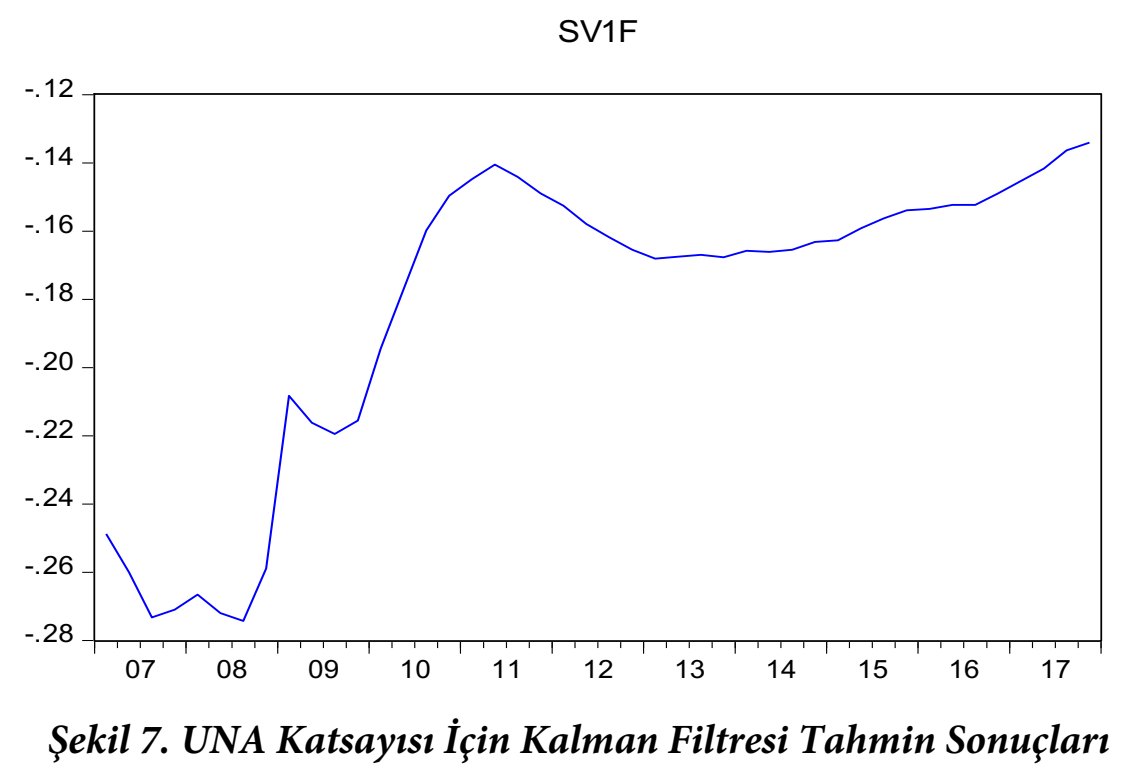

Şekil 7'de gösterilen zamana göre değişen parametre tahmin (TVP) sonuçlarına göre, ekonomik büyüme yetişkin işsizlik oranları üzerinde de negatif etkiye sahiptir. Şekil 7 incelendiğinde, 2008:Q1-2008:Q3 dönemi arasında büyümenin yetişkin işsizlik üzerindeki etkisinde artış, 2008 yılının son çeyreğinde ise söz konusu etkide azalma görülmektedir. Ekonomik daralmanın gerçekleştiği 2009:Q1-2009:Q3 döneminde ise büyümenin yetişkin işsizlik üzerindeki etkisinde küçük bir artış gerçekleşmiştir. TVP sonuçlarına, ekonomik büyümenin yetişkin işsizlik üzerindeki etkisinin, 2009:Q3-2011:Q2 döneminde azaldığ1, takip eden 2011:Q2-2013:Q1 dönemi arasında arttıktan sonraki dönemde etkinin tekrar azalmaya başladığını göstermiştir.

\section{Sonuç}

Global ölçekte olduğu gibi Türkiye'de de, yetişkin işsizlik oranlarının iki katından fazlasını oluşturan genç işsizliğin yıllar itibariyle yüksek oranlarda gerçekleşmeye devam etmesi, genç işsizlik sorununun ayrı olarak incelenmesini gerekli kılmaktadır. Genç işsizliğin konjonktürel oynaklığının yetişkin işsizliğe göre yüksek olduğu ve ekonomik krizlerin genç işsizlik üzerinde daha etkili olduğuna ilişkin ampirik literatürde yapılmış çalışmalar olmasına karşın, Türkiye'de konu ile ilgili uygulamalı çalışma eksikliği olduğu gözlenmiştir. Bu çalışmada, Türkiye için 2006-2017 dönemi çeyreklik verileri ile genç işsizlik ve yetişkin işsizlik oranlarının ekonomik büyümeye duyarlılığı Sınır testi, ARDL modeli ve Kalman Filtresi yöntemi ile araştırılmıştır. Diğer bir ifade ile konjonktürü temsilen ekonomik büyümenin, genç ve yetişkin işsizlik üzerindeki göreli etkisi araştırılmıştır. Bu çalışmada, Türkiye için yapılmış çalışmalardan farklı olarak, genç ve yetişkin işsizlik ile ekonomik büyüme arasındaki ilişki ve küresel finans krizinin genç ve yetişkin işsizlik üzerindeki etkileri dinamik olarak incelenmiştir.

Sınır testi sonuçları, büyüme ile genç işsizlik ve büyüme ile yetişkin işsizlik arasında eşbütünleşme ilişkisi olduğunu göstermiştir. Seriler arasında eşbütünleşme ilişkisi bulunduktan sonra, büyümenin genç işsizlik ve yetişkin işsizlik üzerindeki uzun ve kısa dönemli etkileri ARDL modelleri ile incelenmiştir. ARDL modelleri sonuçlarına göre; büyüme, genç işsizlik üzerinde yetişkin işsizliğe göre uzun dönemde 1.64 kat, kısa dönemde 1.37 kat daha fazla etkiye sahiptir. Kalman filtresi sonuçları, ARDL model sonuçlarını destekleyerek büyümenin yetişkin işsizliğe göre genç işsizlik üzerinde daha yüksek etkisinin olduğunu göstermiştir. Küresel finans 
krizine denk gelen dönemlerde, ekonomik büyümenin genç işsizlik üzerindeki negatif etkisi yetişkin işsizlik üzerindeki negatif etkisinden daha fazla olmuştur. Diğer bir ifade ile Türkiye'de küresel kriz döneminde gerçekleşen ekonomik daralma dönemlerinde, işsizlik bazında gençler yetişkinlerden daha çok zarar görmüştür. Küresel finans krizi dönemi sonrasındaki dönemlerde de, genç işsizlik ekonomik büyümeye yetişkin işsizlikten daha duyarlı olmaya devam etmiştir. Bununla birlikte, büyümenin yetişkin işsizlik üzerindeki etkisi son 4 yllda, genç işsizlik üzerindeki etkisi son 4 çeyrekte azalma göstermiştir.

Türkiye'de kadınların genç işsizlik oranları erkeklerin genç işsizlik oranlarından yaklaşık 1.5 kat daha fazladır. Eğitim türleri arasında en yüksek genç işsizlik yükseköğretimde görülmekte olup, yükseköğretim mezunu kadınların genç işsizliği erkeklere göre oldukça yüksek düzeylerde gerçekleşmektedir. 2017 yllı itibariyle, ne eğitimde ne istihdamda olan gençlerin (NEET) yaklaşık \%70'ini kadınlar oluşturmaktadır. Yükseköğretim mezunu NEET oranı \%35,9 olup, yükseköğretim mezunu NEET içerisinde kadınların payı yaklaşık \%58,5'tir. Türkiye'de kadın/erkek genç işsizlik oranlarının düşürülmesine ve en yüksek genç işsizliğin görüldüğü yükseköğretim mezunlarının istihdamının arttırılmasına yönelik politikalar uygulanmalıdır. Bu amaçla, kadın istihdamı ve eğitimlerini tamamlayıp işgücü piyasasına girmek isteyen gençlerin istihdamı vergi teşvikleri ile desteklenmelidir. Özellikle yükseköğretim mezunlarının yüksek olan NEET oranlarının nedenleri araştırılmalı ve eğitimli atıl işgücü potansiyeli ekonomiye kazandırılmaya çalışılmalıdır.

Çalışmada, 25+ yaş grubu işsizlik oranlarında olduğu gibi, en yüksek işsizlik oranlarının gerçekleştiği 15-24 yaş grubundaki işsizlikle mücadele için ekonomik büyüme oranlarında artış olması gerektiği sonucuna ulaşılmıştır. Uygulamalı analiz sonuçları, ekonomik büyüme oranlarındaki artışı özellikle genç işsizlik oranlarını azaltmada etkili olduğunu göstermiştir. Genç işsizliğin büyüme trendine bağlılığının yüksek olmasının yanında, TVP sonuçlarının gösterdiği gibi, büyümenin her iki işsizlik (özellikle yetişkin işsizlik) üzerindeki negatif etkisinin zamanla azalması, işsizliği etkileyen diğer makroekonomik değişkenlerin araştırılmasını ve ekonomik büyümenin istihdamı destekleyecek alanlarda gerçekleşmesini gerekli kılmaktadır.

\section{Kaynakça}

Aslan B. Y. ve Yamak, A. (2015). Türkiye'de 2000-2013 Döneminde Büyümenin Genç İşsizliğe Etkisinin Vektör Otoregresif Model ile Analizi. Siyaset, Ekonomi ve Yönetim Araştırmaları Dergisi, 16. Çalı̧̧̧ma Ekonomisi ve Endüstri İlişkileri Kongresi Özel Sayısı, 317-333.

Baron, S. W. (2008). Street Youth, Unemployment, and Crime: Is It That Simple? Using General Strain Theory to Untangle the Relationship. Canadian Journal of Criminology and Criminal Justice, 399-434.

Bell, D.N.F. ve Blanchflower, D.G. (2010). Youth Unemployment: Déjà Vu?. IZA Discussion Paper, 4705, 1-56. 
Bruno, G. S. F., Marelli, E. ve Signorelli, M. (2014). The Rise of NEET and Youth Unemployment in EU Regions after the Crisis. Comparative Economic Studies, 56, 592615 .

Bruno, G. S. F., Tanveer, M. C., Marelli, E. ve Signorelli, M. (2017). The Short- and Long-Run Impacts of Financial Crises on Youth Unemployment in OECD Countries. Applied Economics, 49(34), 3372-3394.

Caporale, G. M. ve Alana, L. G. (2014). Youth Unemployment in Europe: Persistence and Macroeconomic Determinants. Comparative Economic Studies, 56, 581-591.

Cenger, H. ve Çütcü, İ. (2018). İthalattaki Değişimin Genç Işsizliğe Etkisi: Türkiye Ekonomisi Üzerine Ekonometrik Bir Uygulama. OPUS- Uluslararası Toplum Araştırmaları Dergisi, 8(Gençlik Araştırmaları Özel Sayısı), 485-503.

Choudhry, M.T., Marelli, E. ve Signorelli, M. (2012). Youth Unemployment Rate and Impact of Financial Crises. International Journal of Manpower, 33(1), 76-95.

Çondur, F. ve Şimşir, N. C. (2017). Türkiye'de Eğitim Harcamaları, Ekonomik Büyüme ve Genç İşsizlik İlişkilerinin Analizi. The Journal of International Scientific Researches, 2(6), 44-59.

Çondur, F. ve Bölükbaş, M. (2014). Türkiye’de İşgücü Piyasası ve Genç İşsizlik-Büyüme İlişkisi Üzerine Bir İnceleme, Amme İdaresi Dergisi, 47(2), 77-93.

Dietrich, H. (2012). Youth Unemployment in Europe: Theoretical Considerations and Empirical Findings. Friedrich Ebert Stiftung, 1-40.

Ertuğrul, H. M. (2011). Türkiye'de Elektrik Tüketimi Büyüme İlişkisi: Dinamik Analiz, Enerji, Piyasa ve Düzenleme, 2, 49-73.

Ertuğrul, H. M. (2012). Türkiye’de Döviz Kuru Volatilitesi ve Enflasyon İlişkisi (Doktora Tezi), Hacettepe Üniversitesi/Sosyal Bilimler Enstitüsü, Ankara.

European Commission (2009). Employment in Europe. Lüksemburg, 1-187.

Frimpong, M. J and Oteng-Abayie, E. F. (2006). Bounds Testing Approach: An Examination of Foreign Direct Investment. Trade and Growth Relationships, Munich Personel RePEc Archive, 1-19.

Fougère, D., Kramarz, F. ve Pouget J. (2006). Youth Unemployment and Crime in France. IZA Discussion Paper, 1-41.

Gomez-Salvador, R. ve Leiner-Killinger, N. (2008). An Analysis of Youth Unemployment in the Euro Area. European Central Bank, Occasional Paper Series, 89, 1-43.

Göçer, İ. ve Erdal, L. (2015). The Relationship between Youth Unemployment and Economic Growth in Central and Eastern European Countries: An Empirical Analysis. Çankırı Karatekin Üniversitesi İktisadi ve İdari Bilimler Fakültesi Dergisi, 5(1), 173-188. 
Görlich, D., Stepanol, I. ve Al-Hussami, F. (2013). Youth Unemployment in Europe and the World Causes, Consequences and Solutions. Kiel Policy Brief, 59, 1-11.

Günaydın, D. ve Çetin, M. (2015). Genç İşsizliğin Temel Makroekonomik Belirleyicileri: Ampirik Bir Analiz, Pamukkale Üniversitesi Sosyal Bilimler Enstitüsü Dergisi, 22, 17-34.

Hutengs, O. ve Stadtmann, G. (2014). Youth and Gender Specific Unemployment and Okun's Law in Scandinavian Countries. European University Viadrina, Discussion Paper, 352, 117.

International Labour Organization (ILO) (2016). World Employment Social Outlook: Trends for Youth, International Labour Office, Geneva, 1-48.

International Labour Organization (ILO) (2017). Global Employment Trends for Youth, International Labour Office, Geneva, 1-115.

International Labour Organization (ILO) (2018). World Employment Social Outlook: Trends for Woman, International Labour Office, Geneva, 1-13.

İzgi, B. B. (2012). Genç İşsizliği ve Eğitim ile Olan İlişkisi, Elektronik Sosyal Bilimler Dergisi, 11(41), 295-310.

Jimeno, J. F. ve Rodriguez-Palenzuela D. (2002). Youth Unemployment in the OECD: Demographic Shifts, Labour Market Institutions, and Macroeconomic Shocks. European Central Bank, Working Paper, 155, 1-61.

Kabaklarl, E., Hazel Er, P. ve Buluş, A. (2011). Economic Determinants of Turkish Youth Unemployment Problem: Co-Integration Analysis. International Conference on Applied Economics, ICOAE, 267-272.

Karagöl, E., Erbaykal, E. ve Ertuğrul, H. M. (2007). Türkiye’de Ekonomik Büyüme ile Elektrik Tüketimi İlişkisi: Sınır Testi Yaklaşımı, Doğuş Üniversitesi Dergisi, 8(1), 72-80.

Karahan, P. ve Uslu, N. (2016). Türkiye'de Genç İşsizlik ve Büyüme İlişkisi Üzerine Dinamik Bir Uygulama. Turkish Economic Association, Proceedings of 5th International Conference on Economics, 1528-1540.

Martin, G. (2009). A Portrait of the Youth Labor Market in 13 Countries, 1980-2007. Youth Labor Market, Monthly Labor Review, 3-21.

Narayan, P. K. and Narayan, S. (2005). Estimating Income and Price Elasticities of Imports for Fiji in a Co-integration Framework. Economic Modeling, 22, 423-438.

OECD (2008). Off to a Good Start? Youth Labour Market Transitions in OECD Countries. OECD Employment Outlook, Paris, 25-77.

O’Higgins, N. (2001). Youth Employment and Employment Policy: A Global Perspective, MPRA Paper, ILO, 23698, 1-212. 
O’Higgins, N. (2010). The Impact of the Economic Crisis on Youth Employment: Measures for Labour Market Recovery in the European Union, Canada and the United States. ILO Employment Working Paper, 70, 1-69.

Özer, U. ve Topal, M. H. (2017). Genç İşsizliği, Suç, Göç, İntihar ve Boşanma Düzeyleri İle İlişkili Midir? Türkiye'den Ampirik Bir Kanıt. Kırklareli Üniversitesi İktisadi ve İdari Bilimler Fakültesi Dergisi, 6(5), 50-63.

Pagés, C. ve Montenegro, C. E. (2007). Job Security and the Age-Composition of Employment: Evidence From Chile. Estudios de Economía, 34(2), 109-139.

Pesaran, M. H., Shin, Y. ve Smith, R. J. (2001). Bounds Testing Approaches to the Analysis of Level Relationships. Journal of Applied Econometrics, 16, 289-326.

Ryan, P. (2001). The School-to-work Transition: A Cross-National Perspective, Journal of Economic Literature, 34-92.

Sayın, F. (2011). Türkiye'de 1988-2010 Döneminde Eğitim ve Büyümenin Genç İşsizliğine Etkisinin Analizi. Dokuz Eylül Üniversitesi Sosyal Bilimler Enstitüsü Dergisi, 13(4), 33-53.

Scarpetta, S., Sonnet, A. ve Manfredi, F. (2010). Rising Youth Unemployment During the Crisis: How to Prevent Negative Long-term Consequences on a Generation?. OECD Social, Employment and Migration Working Papers, 106, 1-34.

Tomić, I. (2017). What Drives Youth Unemployment in Europe? Economic vs. Non-Economic Determinants. International Labaour Review, 1-26.

TÜİK. (2018). İstatistiklerle Yaşlılar. TÜİK.

Uslu N. Ç. ve Karahan, P. (2016). Para Politikasının Kredi Faiz Oranlarına Geçişkenliği Üzerine Dinamik Bir Analiz: Türkiye Örneği. Yönetim ve Ekonomi: Celal Bayar Üniversitesi İktisadi ve İdari Bilimler Fakültesi Dergisi, 23(3), 671-690.

Yavuzaslan, K., Damar, Ö., Sözmez, B., Özdaş, B., Uyar, N. ve Akılotu, E. (2017). Türkiye’de Genç İşsizliğinin, İşsizlik Histerisi Hipotezi Çerçevesinde Yapısal Kırılmalar Testi ile Analizi, Aydın İktisat Fakültesi Dergisi, 2(2), 21-32.

Verick, S. (2009). Who Is Hit Hardest During a Financial Crisis? The Vulnerability of Young Men and Women to Unemployment in an Economic Downturn. IZA Discussion Paper, 4359, 1-35. 